\title{
The Ruin: Ancient Imagery in Medieval Poetry
}

\author{
Inna Matyushina* \\ Russian State University for the Humanities, University of Exeter, England.
}

*Corresponding Authors: Inna Matyushina, Russian State University for the Humanities, University of Exeter, England.

\begin{abstract}
The paper is devoted to the analysis of the topos of Ruin in Old English and Latin Poetry. The theme of Ruin is centered on the apothegm sic transit and is closely connected with that of Old Age (according to Christian philosophy of history, going back to St Augustine, a parallelism is established between the age of man and the age of the world). The origins of the topos go back to folklore lamentations (cf. Akkadian and Sumerian laments over ruins), Biblical descriptions of ruined cities, Classical poetry (Virgil's Aeneid, Lucan's Pharsalia), St Augustine's De civitate Dei, Orosius's Historiarum adversus paganos libri septem and Gildas's De excidio et conquestu Britanniae. The discovery of the individual in the Middle Ages transforms an ancient topos encomium urbis (glorification of Rome) into a poignant lyrical subject de excidio urbis, which is prompted by the destruction of Rome and by the Christian association of earthly cities with sin. Thus the theme of Ruin is as polygenetic as lyrical poetry itself and goes back to the same sources.
\end{abstract}

KEYWORDS: Old English, ruin, Latin poetry, lyric, topical motif.

The beauty and the mystery of a small fragment of 45 lines makes it stand out among extant monuments of Old English poetry; some of its lines are impossible to read, in the central part (lines 12-17) only a few isolated words can be deciphered. Publishers call the surviving fragment 'The Ruin', as it describes a city deserted by its inhabitants and destroyed. The poem is included into the manuscript of the Exeter Book [1], which was presented by Bishop Leofric to the Cathedral Library in Exeter shortly before his death in 1072. The prominence of the motif of ruins in this poem of the Exeter Book can be accounted for by its composition during one of the most unstable periods of English history, marked by the mutinies of Mercian and Northumbrian lords, the raids of the Vikings, and the desolation of buildings. The poem is a meditation on the transience of worldly glory (Fell [2]), which comprises a series of living pictures, juxtaposing images of past magnificence and contemporary decay: the present with its desolated cities is reassessed against the background of past glory. The concept of nostalgia is frequently mentioned by scholars in connection with the Old English 'Ruin', which was called 'an imaginative nostalgia for a glorious past, stimulated by a particular scene spread out before the poet's eyes' (Leslie, [3]) and was said to embody a "nostalgia for a past that is unbroken, inhabitable, articulate and contiguous as well as a reminder of the speaker's own present state of brokenness, isolation, fallenness, and silence' (Liuzza, [4]). The poem permits various interpretations, which range between historical$\operatorname{archaeological}^{1}$ and allegorical ${ }^{2}$, and account for its special impact on the audience both medieval and modern.

The first lines of the poem (Wrætlic is pes wealstan, / wyrde gebræcon ${ }^{3}$, 'This wall-stone is wondrous; calamities broke it') briefly summarise its theme, reminding the audience that all the works of man are as transient as himself. Attention is first drawn to the fate of the buildings (burgstede burston, / brosnad enta geweorc, 2, 'these city-sites crashed, the work of giants is decaying'), and then to its builders

\footnotetext{
${ }^{1}$ Historical-archaeological interpretations concentrate on analysing archaeological, architectural, historical and other extra-linguistic evidence with a view to identifying the place described in the poem (cf. Herben, [5], Herben, [6].

${ }^{2}$ Allegorical explanations of the poem range from suggesting a Christological interpretation (Murgia [7]) and defining the poem as a metaphor for Christ (Cammarota, [8]) to viewing it as a description of the fall of Babylon (Keenan, [9]), or as a body-city riddle (Johnson [10]).

${ }^{3}$ The text of 'The Ruin' is quoted from: Klinck [11].
} 
(Eorðgrap hafað / waldend wyrhtan, $6 \mathrm{~b}-7 \mathrm{a}$, 'The grip of the earth holds the mighty builders'). The perfection of human creation in the past is visualised by the poet as bright halls of the city, magnificent bath-houses, lofty peaked roofs, mead-halls filled with merry human voices: all is full of happiness and joy. Suddenly the imagery changes: pestilence takes human lives, the city collapses, only ruins are left where once happy people were enjoying the abundant gifts of life in their mead-halls. The buildings become desolate: red curved roofs collapse, ceiling-vaults fall to the ground, even the ruins crumble into mounds, symbolising human mortality. At the end of the poem the focus is narrowed again, from description of the ruins to representation of hot springs. The last lines of the manuscript cannot be deciphered with any certainty, but their main drift can be guessed: the splendour of the past is contrasted with a dismal present.

The abundance of picturesque details suggests that the creator of the poem is describing his personal experience: his memories of the past magnificence of cities, the might of people long gone, and the glory of those who once inhabited the dwellings, all come to life in his meditations before the ruins. The description of visualised edifices does not exclude identification with a specific place in England, possibly the ruins of the Roman baths, the Aquae Sulis, which were taken by the Saxons after the battle of Deorham in 577. As has been pointed out by editors, 'there is no evidence to show that Bath (or Acemannesceater, as it is called in the Anglo-Saxon Chronicle, 973A) was ever completely in ruins or desolate' (Krapp, [1]), however other scholars ${ }^{4}$ suggest that in the eighth century, when the poem was allegedly composed, the city of Bath could have decayed (Wentersdorf, [13]) $)^{5}$. Other identifications of the ruined city described in the poem have been proposed (Hadrian's Well, Chester, Caerleon) ${ }^{6}$. It has been suggested that 'as a traveller in an antique land the poet looks on an alien civilisation' (Fell, [2]), therefore he is 'undoubtedly describing Roman ruins, as relatively few Anglo-Saxon buildings were of stone' (Fulk, Cain, [22]). However, as will be shown in this paper, no identification is vitally important for the understanding of the poem, as it deals with a lyrical commonplace, a topos inherited from preceding literary traditions.

'The Ruin' seems to be independent of the gnomic tradition permeating the whole of Old English lyrical poetry: all kinds of moralising or didactic statement are totally absent from this poem ${ }^{7}$. It does not explicitly express Christian or pagan views whose intricate synthesis characterises many Old English poems. The poem is strikingly objective, with no actions taking place during the monologue ${ }^{8}$. If any events at all take place, they do so not in the past and not in the narrative 'reality', but in the imagination of the creator of the poem, for whom the past becomes more visible than the ruin and desolation beheld in the present. By belonging simultaneously to both the present and the past, 'ruins are particularly well suited to signifying this complex and paradoxical understanding of temporality' (Trilling, [23]). The theme of time determines the composition and the structure of the poem, based on the contrast between the past and the present ${ }^{9}$ : only the imagination of the individual beholding the ruin can overcome the destructive might of time. The device of contrast dominates this poem, in which every statement contrasts with the previous and the following: 'This wall-stone is wondrous' : 'fates broke it'; 'Roofs have fallen, towers in ruins': 'Bright were the castle buildings'; 'The grasp of the earth has taken mighty builders': 'many warriors, joyful $<\ldots>$ gazed at treasure'. Contrast between the past and the present is underlined by shifts between present and past verbal forms which permeate the poem, starting from its first lines: Wrætlic is pes wealstan, wyrde gebræcon, 'This wall-stone is wondrous, fates broke it'; 'burgstede burston, brosnad enta geweorc', 'the castles decayed, the work of giants is crumbling' ${ }^{10}$. As was pointed out by Renée Trilling, 'the poem balances a series of dialectal tensions - present/past, death/birth, decay/wholeness, inside/outside, material/ideal - without privileging one over the other'

\footnotetext{
${ }^{4}$ The general consensus among scholars is that if any specific city is described in the Old English 'Ruin' it is Bath (cf.: Hotchner, [12], Wentersdorf, [13], Lee,[14], Greenfield, [15]

${ }^{5}$ Barry Cunliffe points out that 'by the eighth century enough of the superstructure, less the vaults, was still standing to be intelligible to the Anglo-Saxon poet' (Cunliffe, [20]).

${ }^{6}$ For the identification of the ruined city as Hadrian's Well see Herben, [5], Herben, [6]. For the city identified as Chester see Dunleavy, [16]; for comments on Caerleon see Wentersdorf, [13].

${ }^{7}$ Some scholars have expressed opposite views, arguing that the poem is composed as a warning against the sins of pride, lust and luxury (Doubleday, [17]. Doubleday views 'wlonc ond wingal' as a formula which accounts for the destruction of the city in 'The Ruin'.

${ }^{8}$ Marc Amodio called 'The Ruin' 'more dispassionately ruminative than intensely emotional' (Amodio, [18]).

9 Time and Fate were identified as the two 'characters' of the Old English 'Ruin' (Murgia, [7] ).

${ }^{10}$ Calder views the 'shifting tenses' as constructing the reader's perspective of temporality through the speaker's train of thought (Calder, [21].
} 
(Trilling, [23]). The contrast of temporal perspectives can be called the basic structural principle of the Old English 'Ruin'.

The contrast between the past and the present, which is embodied in the image of a deserted mead-hall, can be found in the lyrical fragment of Beowulf, containing the lament of a father for his son: Gesyhð sorhcearig / on his suna bure // winsele westne, / windge reste //

reote berofene. / Ridend swefað, // hæleð in hoðman; / nis pær hearpan sweg, //gomen in geardum, / swylce ðær iu wæron (2456-2460) ${ }^{11}$, 'With sorrow he beholds the dwelling of his son, deserted winehall, wind-swept lodging, deprived of noise. The riders sleep, warriors in their graves, there is no sound of the harp, of the joy in the courts which once was there'. Scholars have suggested that the lament of the father for his son is 'as far as it can be from the triumphant note of 'The Ruin'" (Fell, [2]), however the theme of both lyrical passages is the same. As in 'The Ruin', the dwelling, which was once full of joy and happy feasting, is presented in the lyrical fragment of Beowulf as desolate and waste: the people who inhabited it in the past are in their graves, and only the wind blows through their empty buildings.

The description of the deserted city included into the Old English poem 'The Wanderer' is even closer to the imagery of 'The Ruin': ponne ealre pisse worulde wela / weste stondeð, // swa nu missenlice / geond bisne middangeard //winde biwaune / weallas stondap, // hrime bihrorene hryðge pa ederas.// Woriað pa winsalo, / waldend licgað // dreame bidrorene, / dugup eal gecrong, // wlonc bi wealle ${ }^{12}$, 'when all the wealth of this world lies waste, as now in various places throughout this middle-earth, walls stand, blown by the wind, covered with frost, storm-swept the buildings. The halls decay, their lords lie deprived of joy, the whole troop has fallen, proud by the wall (74-80a). In 'The Wanderer' the description of the ruin is one of many images determining the complex architectonics of the poem, whereas in 'The Ruin' the description of deserted buildings constitutes the only theme of the poem. Scholars have concentrated on the dissimilarities of 'The Wanderer' and 'The Ruin' (Liuzza, [4]; Lee, [14]), however the two poems share a number of common motifs and images. In both poems the fate of a human being is implicitly likened to the destiny of cities and buildings erected by people for their enjoyment. In both, the theme of universal transience is symbolically expressed in the images of ruined cities and deserted buildings. The description of the decay and desolation of buildings in both the 'Wanderer' and 'The Ruin' includes a number of parallels both of specific motifs (e.g., human beings confined to their graves, people who were once happy now deprived of joy, buildings laid waste, frost clinging to mortar) and in verbal details ('wlonc ond wingal', 'proud and flushed with wine' in the 'Ruin', 'wlonc bi wealle', 'proud by the wall' in the 'Wanderer'). The inner world of the lyrical heroes (their microcosms) acquires a macrocosmic significance through the images of desolate buildings, which in past days served as safe dwellings and harbours of happiness.

The image of a grave, concealing the warriors and the builders alike, is symbolically widened to encompass the whole universe: the fortresses of the giants (enta geweorc, 87), which are destroyed and laid waste, resemble an enormous cemetery full of monuments to past glory. The values of the heroic world: 'the joys of palaces' (seledreamas) and 'the halls of feasts' (symbla gesetu) have turned to dust, but have become more precious for the lyrical persona, because they are gone forever. Understanding that in this world all that he loves is mortal, and therefore must be irretrievably lost, fills his soul with sorrow and grief, but it teaches him humility and resignation. Lyrical nostalgic notes give way to a Christian conceptualisation of the universal transience of sublunary nature. The main themes of 'The Wanderer' and 'The Ruin', the destruction of earthly creations, human mortality and resignation to the inevitability of death, appear in Old English lyrical poetry from the perspective of the Holy Scriptures.

One of the most striking descriptions of the destruction of cities is contained in the final book of the New Testament, 'The Book of Revelation' (18:2-23). The fall of Babylon is seen as well deserved and just, because the city was full of evil: 'in one hour all its great wealth has been brought to ruin!' $(18: 17)$ : no one will buy their cargoes anymore (18:11), its luxury and splendor have vanished, never to be recovered (18:14). There is a striking difference in the description of the fall of Babylon in 'The Book of Revelation' and the destruction of cities in Old English lyric: in the former the city is destroyed as a

\footnotetext{
11 The text of Beowulf is quoted from: Klaeber, [19].

12 The text of 'The Wanderer' is quoted from: Klinck, [11].
} 
just punishment, whereas in the latter the destruction of cities is described with grief and nostalgia ${ }^{13}$. In Old English poetry the attention of the audience is focused on the loss of happiness and human mortality. The Biblical descriptions of ruins are associated with human sinfulness and unrighteousness, since they occur in a cultural context different from that of Old English poetry ${ }^{14}$.

In their tone, the Old English images of desolate buildings are closer to mournful laments over ruined cities in the Old Testament to than to the description of the Fall of Babylon in 'The Book of Revelation'. In the 'The Book of Isaiah', the motif of ruin appears in the lament about the sudden destruction of Moab (15:1-9), in the warning that 'Damascus will no longer be a city but will become a heap of ruins. ... The fortified city will disappear from Ephraim, and royal power from Damascus' (17: 1-3), and in the prophecy about the destruction of Tyre (23). The destruction of these cities in 'The Book of Isaiah' shares similar motifs and images with the Old English poem, such as the motif of vanished glory ('the glory of Jacob will fade', 17:4), the motif of merriment and joy in the past and silence in the present ('gladness and joy shall be taken away from Carmel, and there shall be no rejoicing nor shouting in the vineyards, 16:10), the image of a harp ('Take a harp, go about the city, 23:16), the motif of pride ('The Lord of hosts hath designed it, to pull down the pride of all glory, and bring to disgrace all the glorious ones of the earth', 23:9). In the Old Testament, dwellings are turned into ruins according to God's will: 'For He shall bring down them that dwell on high, the high city He shall lay low. He shall bring it down even to the ground; He shall pull it down even to the dust (26:5). Thus similarly to the Old English 'Wanderer', the reason for the destruction of cities is stated clearly and bluntly: human pride leads to desolation.

In contrast to 'The Book of Isaiah', where the description of the ruin is a marginal motif, in the 'Lamentations of Jeremiah' the destruction of the city (Jerusalem) becomes the predominant theme: the gates are broken ('all her gates are broken down', 1: 4), walls are destroyed ('the wall hath been destroyed together', 2:9), fortifications are ruined ('he hath overthrown all the walls thereof: he hath destroyed his strong holds, 2: 5), only scattered stones are lying in the streets ('the stones of the sanctuary are scattered in the top of every street', 4:1). The inhabitants of the city are gone: ('The Lord hath taken away all my mighty men', 1:15); feasts exist only in the past ('The Lord hath caused feasts and Sabbaths to be forgotten', 2:6), the city which was once full of inhabitants is now empty ('How doth the city sit solitary that was full of people!' 1:1). The main structural principle in the 'Lamentations' is the contrast between former glory and present desolation (4:1-11), which is present in both the Old English 'Ruin' and the 'Wanderer'. The destruction of the city is described with the help of similar motifs in both the 'Lamentations of Jeremiah' and the Old English 'Ruin': the destruction of gates (steap geap gedreas, 'high gate has collapsed'), the fall of fortifications (hreorge torras, 'ruinous towers'), the collapse of the walls (weal eall befeng, 'the wall enclosed all'), the death of the inhabitants of the city (wylt eall fornom secgrofra wera; wurdon hyra wigsteal westen stapolas, brosnade burgsteall, 'death swept all the brave men away; their war-fortresses became waste places, the city decayed'). As in the Old English poems, the destruction of the city is depicted in the 'Lamentations of Jeremiah' in a detached generalized style, not as if it had taken place in the eyes of the beholder. The description of material ruins in the 'Lamentations of Jeremiah' gives way to their symbolic significance: architectural details are less important than the impact of the destruction of cities on the present and future.

The tradition of the Old Testament 'Lamentations' is reflected in St Augustine's De excidio urbis Romae sermo, in which he analyses both the causes of the fall of Rome and the doom impending over any worldly city ${ }^{15}$, and in his De civitate Dei, which also examines the decline of the Roman Empire ${ }^{16}$ under the impressions of the destruction of Rome by Alaric and the Visigoths in 410. The City of God or Heavenly City (civitas Dei or civitas caelestis) is inhabited by those who reject earthly pursuits and devote themselves to God and the eternal truths of the Christian faith. The Earthly City (civitas terrena)

\footnotetext{
${ }^{13}$ The parallel between the Old English 'Ruin' and the fall of Babylon was first drawn by Keenan [9], but the differences, making the parallel unconvincing, were summarised by Doubleday [17].

14 The difference in the cultural context has even led scholars to the conclusion that the motif of ruin does not exist in Old English poetry and has no relevance to the Biblical tradition (Hume, [24]).

${ }^{15}$ Woods, [25] argues that the earthquake described by St Augustine is a historical event which took place in Constantinople 1 April 396.

16 Parallels between the Old English 'Ruin' and St Augustine's De civitate Dei, Orosius' Historiae adversos paganos and Gildas' De exidio et conquestu Britanniae were drawn by Doubleday [17].
} 
is inhabited by ordinary people and is not, as such, evil: its times of peace, relative well-being and earthly goods are 'undoubtedly gifts from God' (sine dubio Dei dona ${ }^{17}$ ) and therefore people should be grateful for them. The danger lies in the inhabitants of the Earthly City neglecting the values of the City of God and satisfying only their worldly desires, focusing exclusively on earthly matters, objects of vanity and on pleasures of the present, passing world. Then there is no salvation in the Earthly City: 'necessarily miseries will follow and increase' (necesse est miseria consequatur et quae inerat augeatur). St Augustine's historical-philosophical treatise is permeated with sorrow for the follies of those who doom themselves and their city to destruction through their own obliviousness to the Heavenly: it is not fate which is to blame for the desolation of cities, but those who fail to understand that spiritual ends are more important than worldly ends, and consequently do not keep the Kingdom of God in mind as their ultimate goal. It is possible to suggest that the description of the destruction of cities in Old English poetry is closer to the tradition of St Augustine than to that of the 'Book of Revelation'.

One response to St Augustine's request for arguments against pagan opponents of Christian faith who blamed the Church for the fall of Rome was Paulus Orosius' treatise, Historiarum adversus paganos libri septem (Bately, xciii). In his History, Orosius follows the line of argument of St Augustine, who in the third book of De civitate Dei shows misfortunes haunting Rome from its foundation, in order to demonstrate that the veneration of pagan gods did not relieve the Romans from calamities. Orosius presents the whole history of the world as a succession of four empires (Babylon, pagan Rome, Macedonia and Carthage), each growing out of the ruins of the preceding, and specifies causes for the destruction of Babylon and Rome. His description of the latter concentrates on military defeat, plague, earthquake, fire, and the invasion of the Gauls, who poured into the defenseless city, setting fire to the houses, "the flames cremating the bodies and the falling roofs burying them $<\ldots>$ When the Gauls had departed, only offensive heaps of shapeless ruins remained within the circuit of the former city. Everywhere the echo of the voices of those who wandered amid the obstructions, ignorant where their own property was, resounded and kept ears alert. The very silence was terrifying; for loneliness in the open is in itself a cause of fear' ${ }^{18}$. The description of the fall of Rome by Orosius is characterised by the use of motifs similar to those of 'The Ruin': fallen roofs (in 'The Ruin': Hrofas sind gehrorene, 'roofs are fallen'), only heaps of ruins left of former glory (in 'The Ruin': Hryre wong gecrong gebrocen to beorgum, 'The ruin has fallen to the ground broken into mounds'), silence over the desolate city (in 'The Ruin': Forpon pas hofu dreorgiað, 'so these buildings grow desolate'). The description of both Rome and Babylon is reproduced in the Old English translation of Orosius initiated by King Alfred, in which the same motifs as in the Old English poems are preserved: Babylon, which was the first among cities, is described as lying waste, its gates and walls which have collapsed tell all mankind of its fallen might. In both the Latin original and the Old English translation the conclusion is the same: the glory of Rome, as formerly the pride of Babylon, was destroyed by God's will, in punishment for human sins.

Orosius had high authority in medieval England and was quoted by Aldhelm, Bede the Venerable and Gildas. Gildas' sermon 'De excidio et conquestu Britanniae' ('On the Ruin and Conquest of Britain') presents a history of Britain with the single purpose of moral exhortation. Starting from the description of flourishing cities, Gildas shows how the inhabitants of Britain stopped giving praise to God and wallowed in sin, arrogance, lying, cruelty, corruption, luxury and ignorance. Consequently the Lord deserted Britain, leaving it to its own faults. British leaders invited the Saxons, who came and devastated the land: 'columns were levelled with the ground by the frequent strokes of the battering-ram, all the husbandmen routed, together with their bishops, priests, and people, whilst the sword gleamed, and the flames crackled around them on every side. Lamentable to behold, in the midst of the streets lay the tops of lofty towers, tumbled to the ground, stones from high walls, holy altars, fragments of human bodies $\langle\ldots\rangle$ with no chance of being buried, save in the ruins of the houses ${ }^{19}$. With graphic detail, Gildas describes the deaths of people, cities abandoned by their inhabitants, high towers lying in dust, demolished buildings witnessing to God's anger and warning to sinners. The expressive visualisation of the ruins in 'De excidio et conquestu Britanniae' suggests that Gildas, like the creator of the Old English 'Ruin', could have been basing his work on accounts of first-hand witnesses.

\footnotetext{
${ }^{17}$ St Augustine's De Civitate Dei is quoted from: Dombart, Kalb, [26].

18 The text of Paulus Orosius is quoted from: Orosius, [27].

19 The text is quoted from: Gildas and Nennius, [28].
} 
Gildas's treatise served as a source of inspiration for a famous scholar of the Carolingian Renaissance, Alcuin, who referred to the author of 'De excidio' as 'Gildas sapientissimus'. It was under the influence of Gildas that Alcuin composed his poem 'On the destruction of Lindisfarne monastery' ('De clade Lindisfarnensis monasterii'). In Alcuin's elegy, 'references to the glories of Lindisfarne, including St. Cuthbert, are overshadowed by lamentation for its present desolation and the widespread ruin and destruction throughout the once glorious Roman empire' (Schlauch, [29]). Alcuin compares the sad fate of Lindisfarne with the fall of Rome, Jerusalem and Babylon, viewing it not only as punishment sent to the people of Northumbria for their sins (according to early Medieval annalists, Viking raids were seen as God's punishment as foretold by the prophet Jeremiah: 'Then the Lord said unto me, Out of the north an evil shall break forth upon all the inhabitants of the land', 1:14) but also in accordance with the Old English lyrical tradition of the transience of all worldly creations. Starting from the Fall of man and the expulsion of Adam from Paradise, after which calamities and misfortunes determined human destiny, Alcuin describes the destruction of Babylon, Jerusalem and Rome, and then narrates the events of the immediate past and the present: then 'the whole of Italy was moaning during the Gothic invasion', 'for nine years the whole of Gaul was suffering from Hunnish swords', and now still 'wide Asia is groaning under the yoke of heathens', 'Africa, the third part of the great world, is enslaved', 'people of Spain are oppressed by the power they hate' (77-81). Alcuin moves on to the destruction of Lindisfarne, which was attacked by the heathens from the north: they destroyed buildings of the monastery, ransacked libraries and scriptoria, slaughtered priests and monks:

\begin{tabular}{|l|l|}
\hline Sic maior magnis subito saepissime rebus & $\begin{array}{l}\text { Thus unexpectedly the greatest works come to even } \\
\text { Eveniet casu forte ruina malo }\end{array}$ \\
$\begin{array}{l}\text { Haec exempla dedit periturus et undique mundus, } \\
\text { Divitiis florens, qui perit in pelago. } \\
\text { Voce prophetarum partes per quatuor orbis } \\
\text { Iam praedicta vides subruta regna modo. } \\
\text { Nobilis urbs regno et prima potentia regum } \\
\text { this lesson; its wealth flourishes and is lost in seas. On } \\
\text { the four sides of the world the fall of kingdoms can be } \\
\text { Roma, caput mundi, mundi decus, aurea Roma, } \\
\text { Nunc remanet tantu saeva ruina tibi. }\end{array}$ & $\begin{array}{l}\text { The noblest city in the realm and the main stronghold } \\
\text { of kings, the mighty Babylon, alas, lost the kingdom } \\
\text { of Chaldea. <...> Rome, capital of the world, wonder } \\
\text { of the world, golden Rome, now only wild ruins are } \\
\text { Lutea pars tegetum sola videtur iners } \\
(25-40)^{20}\end{array}$ \\
\hline
\end{tabular}

Alcuin concludes his elegy by addressing the Bishop of Lindisfarne, Higbald, asking him to find consolation for his soul in the thought that all those who perished at the hands of the heathens will forever be with the saints. In his letters to Higbald, Bishop of Lindisfarne, Alcuin states that the reconstruction of the ruins of Rome and Jerusalem should give hope of the restoration of Lindisfarne monastery, but in his elegy, the image of destroyed cities reminds readers of the universal doom impending on all earthly cities. The similarity of the description of the destruction of the monastery in Alcuin's elegy to the images of ruins in Old English poetry lies in the presence of topic motifs of fallen roofs and the loss of former glory, as well as in the contrast between past prosperity and present desolation.

Alcuin based his poem 'On the destruction of Lindisfarne' not only on the treatises of Gildas and Orosius but also on the poetic works of the Gallic and Italian poets of the 5-6 $6^{\text {th }}$ centuries. The destruction of the urban civilisation of Antiquity, which gave way to the peasant culture of the Middle Ages, the fall of the Roman Empire, and the invasion of Germanic tribes supplied all the extra-linguistic conditions necessary for the development of the motif of ruin. Whereas the literary tradition of Antiquity created panegyrics describing and glorifying cities in the genre of encomium urbis, in the Middle Ages, which inherited from Antiquity only the ruins of urban culture, a new lyrical genre was cultivated: de excidio urbis focussing on the apophthegm sic transit.

The lyrical genre of de excidio urbis is found not only in Western European but also in Middle Eastern poetry. A Persian poet and prose-writer, Afzal al-Dīn Badīl ibn 'Alī ibn 'Othmān, commonly known as Khāqānī, composed a qasida on 'The Ruins of the City of Madaen': Hān ey del-e 'ebrat-bin az dida 'abar kon hān/ayvān-e madā'en rā āyina-ye 'ebrat dān, 'My spirit, behold the transient world with the

\footnotetext{
${ }^{20}$ The text of Alcuin's De clade Lindisfarnensis monasterii is quoted from: Poetae Latini aevi Carolini, [30].
} 
eyes of meditation; read fate in the deaf ruins of Madaen as in the mirror'. The ruins of fortified towers in Khāqānī's poem narrate the sad story of their destruction: 'you are made of clay and we have become poor clay, / And formerly we sparkled with wealth, might and beauty $<>$ We were erected by justice and we were destroyed by mighty yoke. Behold, this is how the whirl of time will erase palaces of tyrants! By whom was the beauty of these proud walls and towers destroyed? Did heaven erase them or the power which rotates the skies?' Khāqānī's qasida is based on the same structural principle as the Old English 'Ruin', contrast between the past and the present. In the past the city of Madaen could boast of might and splendour; now it lies in ruins. The motif of pride is present in both the Old English 'Ruin' ('wlonc ond wingal', 'proud and flushed with wine') and Khāqānī's qasida ('proud walls and towers'). In contrast to the Old English poem, in which time is named as the sole culprit of destruction, in Khāqān̄̄'s poem the question of who is responsible for the downfall of the city remains open.

Like Old English poets, Khāqānī refers to the people who used to inhabit those buildings which now are lying in ruins: 'Oh, Madaen, how many faces are concealed by the stone tablets! Processions of silent stone kings are walking along your walls $<>$ Imagine, the gates are the same, palaces and squares are the same. But empty are the stairs and the entrances... Where are the rulers, where are people? Dismount your horse, touch the sacred earth and listen: silence'. Khāqānī warns mighty rulers who owned palaces that they cannot escape the fate of all earthly creations: they will turn to ashes like the ruins of splendid palaces, reminding them of their mortality. The motifs of the silence and emptiness of decayed cities occur in both Khāqānī's poem and the Old English 'Ruin', which are united by the shared theme of earthly transience.

The description of urban ruins is developed in the poem 'De Reditu Suo' by Rutilius Claudius Namatianus, of which only seven hundred lines have survived. Rutilius narrates his impressions of the cities during his voyage from Rome to Gaul in 416, starting his poem with praise of the great city, its founders and its victories. He describes the ruins of Castrum, above which the statue of Pan is still visible (stringimus hinc effractum et fluctu et tempore Castrum: / index semiruti porta vetusta loci', 'Next we coast by Castrum, shattered both by wave and time: an age-worn gateway marks the halfruined place' I, $227-228)^{21}$, and recounts the fall of Cosa caused by rat infestation, 'ridicula causa' ('cernimus antiquas nullo custode ruinas / et desolatae moenia foeda Cosae. / ridiculam cladis pudet inter seria causam / promere, sed risum dissimulare piget. / dicuntur cives quondam migrare coacti / muribus infestos deseruisse Lares!', 'Then we descry, all unguarded now, desolate Cosa's ancient ruins and unsightly walls. It is with a qualm that I adduce mid serious things the comic reason for its downfall; but I am loath to suppress a laugh. The story runs that once upon a time the townsfolk were forced to migrate and left their homes behind because rats infested them!' I, 287-290). The ruin is depicted by Rutilius not as a magnificent image reminding the reader of the glory of past generations but as an unfortunate, annoying, almost embarrassing sight. The description of ruins in Rutilius's 'De Reditu Suo' and in the Old English 'Ruin' is thus strikingly dissimilar ${ }^{22}$.

Like Rutilius who includes into his poem praise of the glory of Rome, another Roman poet, Ausonius, composes a poem, 'Ordo Urbium Nobilium', in the style of encomium urbis about Rome and another thirteen cities of the Roman Empire, in which he depicts the flourishing of architecture on the verge of its catastrophic destruction. However, Ausonius' grandson, Paulinus of Pella, describes the destruction of building and the demise of cities not in panegyrical but in rather mournful verse. In his 'Carmen Eucharisticus', Paulinus recounts the calamities of his life: the invasion of the Germanic tribes, the burning of his city and of his house by the Goths, the siege of the neighbouring city of Bazas, his own life on a devastated and ruined estate. The losses of the lyrical hero are made significant by a detailed narrative of the riches accompanying his former life in his ancestral home: a multitude of servants, sumptuous feasts, ornate silver utensils, huge stables full of pure-bred horses $(200-210)^{23}$. Like the persona of the Old English 'Wanderer' lamenting the loss of his lord, Paulinus mourns the death of his father, which coincided with the destruction of the whole civilisation: "At mihi damna domus populantem inlata per hostem, / per se magna licet, multo leviora fuere / defuncti patris inmodico conlata dolori, / per quem cara mihi et patria et domus ipsa fiebat', 'But for me, the havoc wrought on my home

\footnotetext{
${ }^{21}$ The text and translation of Rutilius Namatianus's poem is quoted from: M. Malamud [31].

${ }^{22}$ The dissimilarity of the description of ruins in Old English poetry and in Rutilius' 'De Reditu Suo' has led scholars to deny the existence of the motif of ruin in Old English poetry (Hume, [24]).

${ }^{23}$ Kathryn Hume points out that Paulinus, unlike the speaker in 'The Wanderer', actually owned all the things he enumerates in his poem (Hume, [24]).
} 
by the ravages of the enemy, though great in itself, was much lighter when compared with my boundless grief for my departed father, who made both my country and my home itself dear to me' $(238-242)^{24}$. On Paulinus, the death of his father inflicted a much harder blow than the ruining of his estate. Moreover Paulinus realizes that his loss of material things was for the better, because when his house was flourishing, abundant in pleasures and delights (cum mihi laeta domus magnis floreret abundans deliciis 435), the thoughts of the owner inevitably turned to transitory luxury. Thus the house is depicted not as a focus of cultural esteem but as a symbol of perishable utilities and worldly comforts (amissis opibus terrenis atque caducis, 441), and its destruction helps the lyrical persona to aspire to eternal values.

The motif of urban decay is given more nostalgic treatment in the elegy, 'De Excidio Thoringiae', by Venantius Fortunatus ${ }^{25}$. The lyrical voice in this poem belongs to the Thuringian-born princess Radegunda, who describes the Frankish destruction of her kingdom of Thuringia ${ }^{26}$ : her palace, which shone in splendour is ruined by enemies; the golden roofs dazzling the onlookers are burned to the ground; the people who inhabited luxurious dwellings are lying dead:

\begin{tabular}{|c|c|}
\hline $\begin{array}{l}\text { Conditio belli tristis, sors invida rerum! } \\
\text { Quam subito lapsu regna superba cadunt! } \\
\text { Quae steterant longo felicia culmina tractu } \\
\text { victa sub ingenti clade eremata iacent. } \\
\text { Aula palatino quae floruit antea cultu, } \\
\text { hanc modo pro cameris maesta favilla tegit. } \\
\text { Ardua qaue rutilo notuere ornata metallo, } \\
\text { pallidus oppressit fulgida tecta cinis missa sub hostili } \\
\text { domino captiva potestas, } \\
\text { decidit in humili gloria celsa } \text { loco }^{27} \text {. } \\
(1-10) \text {. }\end{array}$ & $\begin{array}{l}\text { O sad condition of war, O fate, envious of things! } \\
\text { With what a sudden collapse have proud } \\
\text { kingdoms fallen! The pinnacles, which stood } \\
\text { happy for so long, lie conquered, burned, by great } \\
\text { disaster. The regal palace which was once a place } \\
\text { of elegant opulence is now roofed by dismal } \\
\text { cinders instead of vaults. The high glittering roofs } \\
\text { which once shone, adorned with red-gold metal, } \\
\text { are now smothered by pale ashes. Power was sent } \\
\text { as a captive to a hostile lord; lofty glory sank into } \\
\text { a humble place. }\end{array}$ \\
\hline
\end{tabular}

Venantius' elegy has greater resemblance to Old English meditative lyrical poetry in its description of ruins than to any other poetic or prose work mentioned above. Like the Old English 'Ruin' (and in contrast to the 'Wanderer' where earthly decay is depicted in general terms), the elegy 'De Excidio Thoringiae' contains the description of a specific place. Like the creator of the Old English 'Ruin', Venantius contrasts decayed buildings without roofs with grand edifices with golden tops which had happily stood for centuries (3-6, 22). The narrative of past joys (cf. 'The Wanderer', 41-45, 'The Ruin', 25-26) makes the description of present decay all the more poignant and moving (cf. in Venantius' elegy 17: 'Alas, unburied corpses cover the field'). In both poems, the Old English 'Ruin' $(1,24)$ and 'De Excidio Thoringiae', the predominant motif is that of inescapable fate ${ }^{28}$ ('sors invida rerum!', ' $O$ fate envious of things!' 1; 'Consuluit fortuna viris quos perculit hostis', 'Fortune appointed the destiny to those whom an enemy' killed, 35). In Venantius' elegy, fate or fortune is referred to in the singular (sors, fortune), however in the Old English 'Ruin' the noun wyrd ('fate') is used both in the singular ('oppæt pæt onwende wyrd seo swipe', 'until mighty Fate changed that', 24) and in the plural ('wyrde gebræcon', 'fates broke it') in the first line of the poem. The plural of the word for fate (wyrde) brings to mind the goddesses of fate (Fata, Fates) in pagan mythology and the three norns Urðr (Wyrd), Verðandi and Skuld who shaped the fates of both people and cities alike, determining their demise.

In Venantius' elegy, the fall of Thuringia is compared to the fall of Troy: 'Let Troy be not the only one lamenting its destruction, as, like it, Thoringia suffered from the same calamity' (19-20). The mention of Troy could have been a common-place in rhetorical exercises, which motivated the transition to the description of ruins. As is well-known, accounts of the destruction of Troy are absent from Homeric epic; however, in Latin retellings, such as 'De excidio Troiae historia' by Dares Phrygus or 'Ephemeris belli Troiani' by Dictys Cretensis, the desolation of Troy becomes a subject of literary representation. The description of the destruction of Troy by Dares, in which sympathy is expressed towards the Trojans (rather than Greeks as in Homeric epic), was widely studied in the Middle Ages, since the Romans, as

\footnotetext{
${ }^{24}$ The Latin text of Paulinus' poem 'Carmen Eucharisticus' and its English translation 'Thanksgiving' are quoted from: H.G. Evelyn-White [32].

${ }^{25}$ For a detailed study of the motif of ruin in Venatius' elegy see: Brandl, [33].

${ }^{26}$ The authorship of the poem is disputed: K.Cherewatuk argued that it was composed by princess Radegunda herself (Cherewatuk, [34), whereas B Brennan attributed the authorship to Venantius Fortunatus (Brennan, [35]).

${ }^{27}$ The text of Venantius' elegy is quoted from: Venanti Honori Clementiani Fortunati [36]

${ }^{28}$ On the motif of fate in Old English poetry see: Timmer, [37].
} 
well as the Franks and the Britts claimed to be descended from the Trojans. Dares and Dictys could have inherited the description of the Trojan ruins from Virgil, who must have been the first to introduce the motif of ruins in his Aeneid (Book 12). It is not unlikely that Venantius owes the comparison of Thoringia to Troy to the topic motif going back to Virgil. Starting with the elegy 'De Excidio Thoringiae' by Venantius Fortunatus, whose poem could have been known to the creator of the Old English poem, the description of ruin develops into a topic motif of medieval lyrical poetry.

Thus, in the early Middle Ages the motif of ruin was based on the Old Testament, in which the destruction of cities is viewed as punishment inflicted by God. The description of ruin developed in homiletic and historical literature, in the works of St Augustine, Orosius and Gildas, is responsible for the introduction of this motif in medieval lyric, but with a different function. The destruction of the city is viewed not only as a punishment for sin, but also as an inevitable consequence of universal mortality and transience. Nostalgic tones appear in the lyrical motif of ruin under the influence of the attitude to the destruction of the city in Classical Antiquity: Virgil and later Dares and Dictys describe the burning and ravaging of Troy, viewing Rome with its universal mission as its direct descendent. The fall of Rome gives a new impulse to the development of the poignantly represented lyrical motif of ruin, enriched by the associative bond between earthly city and sin, which was given to world culture by the Holy Scriptures. The discovery of the individual in the Middle Ages transforms an ancient genre, encomium urbis (glorification of Rome), into a lyrical subject de excidio urbis, which is prompted by the destruction of Rome. The repeatability and reproducibility of the motif in medieval lyric (not only European but also Persian, as is confirmed by Khāqānī's qasida), the generalisation of the description of ruins, the shift of accent from the material ruin to the symbolic meaning of the destruction signify the birth of a lyrical topos. Most Medieval poets used the topos of ruin in its semantic and symbolic function, but the Old English poem analysed at the beginning of the present article bears witness that in the Middle Ages ruins were also conceptualised as objects of aesthetic experience. The Middle Ages had as yet discovered neither the ornamental nor the decorative function of ruins, which were only noticed in the Renaissance and cultivated in the Baroque epoch. However the aesthetic perception of ruin is undoubtedly present in the Old English poem included in the $10^{\text {th }}$ century manuscript of the Exeter Book.

\section{REFERENCES}

[1] Krapp, G. P., Dobbie, E.v. K., eds. (1936). The Exeter Book. The Anglo-Saxon Poetic Records: a Collective Edition. Columbia University Press.

[2] Fell, C.E. (1991). Perceptions of Transience. In: The Cambridge Companion to Old English literature, M. Godden, M. Lapidge (eds.). Cambridge: Cambridge University Press, pp. 172-189.

[3] Leslie, R.F. (1961). Three Old English elegies: The Wife's Lament, The Husband's Message, The Ruin. Manchester: Manchester University Press.

[4] Liuzza, R.M. (2003). The Tower of Babel: The Wanderer and The Ruins of history. Studies in the Literary Imagination. Vol. 36, № 1, pp. 1-35.

[5] Herben, S.J. (1939). The Ruin. Modern Language Notes, № 54, pp. 37-39.

[6] Herben, S.J. (1944). The Ruin Again. Modern Language Notes, № 59, pp. 72-74.

[7] Murgia, R. (2010). A Christological Reading of the Ruin. Trames Journal of the Humanities and Social Sciences. Vol. 14 (64/59), № 2, pp. 180-202.

[8] Cammarota, M.G. (1997). The Ruin. Proposta di rilettura. Linguistica e Filologia, № 4, pp. 25-48.

[9] Keenan, H.T. (1966). The Ruin as Babylon. Tennessee Studies in Literature, № 11, pp. 109-117.

[10] Johnson, W.C. (1980). The Ruin as a Body-City Riddle. Philological Quarterly, № 59, pp. 397-411.

[11] Klinck, Anne L. (1992). The Old English Elegies: a Critical Edition and Genre Study. London: Buffalo.

[12] Hotchner, C.A. (1939). Wessex and Old English Poetry, with Special Consideration of The Ruin. New York: Lancaster Press, pp. 11-59.

[13] Wentersdorf, K.P. (1977). Observations on 'The Ruin'. Medium Avvum. Vol. 46, №. 2, pp. 171-180.

[14] Lee, A.T. (1973). The Ruin: Bath or Babylon? A non-archeological investigation. Neophilologische Mitteilungen, № 74, pp. 443-455.

[15] Greenfield, S.B. (1966). A critical history of Old English literature. London: University of London Press.

[16] Dunleavy, G.W. (1959). A De Excidio tradition in the Old English Ruin? Philological Quarterly, № 38, pp. $112-118$. 
[17] Doubleday, J.F. (1972). The Ruin: Structure and Theme. Journal of English and Germanic Philology, № 71, pp. 369-381.

[18] Amodio, M. (2014). The Anglo-Saxon Literature Handbook. Oxford: Wiley-Blackwell.

[19] Klaeber Fr., ed. (1950). Beowulf and the Fight at Finnsburg. Boston: D.C. Heath \& Co.

[20] Cunliffe, B. (2009). Roman Bath Discovered. Stroud: The History Press.

[21] Calder, D.G. (1971). Perspective and movement in The Ruin. Neophilologische Mitteilungen, 72, pp. 442445.

[22] Fulk, R.D., Cain, C.M. (2005). A History of Old English Literature. Oxford: Blackwell Publishing.

[23] Trilling, R.R. (2009). The Aesthetics of Nostalgia: Historical Representation in Old English Verse. Toronto: University of Toronto Press.

[24] Hume, K. (1976). The 'Ruin Motif' in Old English Poetry. Anglia. Vol. 94, pp. 339-360.

[25] Woods, D. (1992). An Earthquake at Constantinople: Augustine's De Excidio Urbis, VI.7 Augustiniana, Vol. 42, №. 3/4, pp. 331-337.

[26] Dombart B., Kalb A. (eds.). (2003). Augustinus, De civitate Dei, XV, iv. In: Corpus Christianorum: Series Latina. Turnhout: Brepols.

[27] Orosius, (2010). Seven Books of History Against the Pagans. Transl. A.T. Fear. Liverpool: Liverpool University Press.

[28] Gildas and Nennius. Early Welsh Histories. (2020). Translated by J. A. Giles. Cardiff: Cockatrice Books. p. 7-43.

[29] Schlauch, M. (1941). An Old English 'Encomium Urbis'. The Journal of English and Germanic Philology, 1941, Vol. 40, № 1, pp. 14-28.

[30] Poetae Latini aevi Carolini. (1881). Dummler E. Berlin: Weidmannos.

[31] Rutilius Namatianus' Going home. De reditu suo. (2020). Ed. and transl. M. Malamud.

[32] Paulinus Pellaeus: Eucharisticus. (1921). Transl. H.G. Evelyn-White. Loeb Classical Library 115. Cambridge, MA: Harvard University Press.

[33] Brandl, A. (1919). Venantius Fortunatus und die angelsachsischen Elegien Wanderer und Ruine. Archiv für das Studium der neueren Sprachen und Literaturen, Bd. 139, pp. 84.

[34] Cherewatuk, K., Wiethaus U. (Eds.) (1993). Dear Sister: Medieval Women and the Epistolary Genre. Philadelphia, Univ. Pennsylvania Press, pp. 20-45.

[35] Brennan, B. (1996). The Disputed Authorship of Fortunatus’ Byzantine Poems. Byzantion, Vol. 66, №. 2, pp. 335-345.

[36] Venanti Honori Clementiani Fortunati Presbyteri Italici Opera Poetica. (1881). Hrsg. Fr. Leo. Monumenta Germaniae Historica. Bd. IV. Berlin: Weidmann, P.271-275.

[37] Timmer, B.J. (1941). Wyrd in Anglo-Saxon Prose and Poetry. Neophilologus, № 26, pp. 24-33, 213-228.

\section{AUTHORS' BIOGRAPHY}

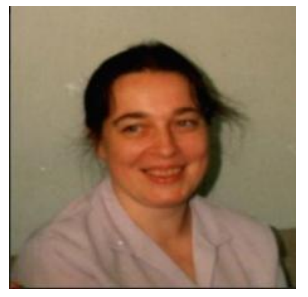

Inna Matyushina is currently leading researcher of the Russian State University for the Humanities (Moscow) and honorary professor of Exeter University. Her publications include the following monographs: Rhyme in Alliterative Verse (1986), The Magic of the Word. Skaldic Libellous Verse and Love Poetry (1994); The Earliest European Lyrics (1999, Two volumes); Skaldic Poetry. Co-authored with Elena Gurevich (2000); The Poetics of Chivalric Sagas (riddarasögur) (2002); Words before blows: The Tradition of Flyting in Old Germanic Culture (2011); and the edited collection The Origin and Development of Lyrical Poetry, with Sergey Neklyudov (2007). She has published over a hundred articles on Old English and Old Norse literature, Old High German epic poetry, issues in translating medieval poetry; she is the editor of Arbor Mundi: The Journal on the History and Theory of Culture (published since 1992). Her current research projects include: Poems of the Anglo-Saxon Chronicle, Old Norse Hagiography.

Citation: Inna Matyushina. "The Ruin: Ancient Imagery in Medieval Poetry” International Journal on Studies in English Language and Literature (IJSELL), vol 8, no. 10, 2020, pp. 44-53. doi: https://doi.org/10.20431/23473134.0810005.

Copyright: (C) 2020 Authors. This is an open-access article distributed under the terms of the Creative Commons Attribution License, which permits unrestricted use, distribution, and reproduction in any medium, provided the original author and source are credited. 